\title{
Водная токсикология
}

УДК 556.555.6(470.316)

\section{ТОКСИКОЛОГИЧЕСКИЕ ИССЛЕДОВАНИЯ МЕЛКОВОДНОГО ВЫСОКОЭВТРОФНОГО ОЗЕРА НЕРО (ЯРОСЛАВСКАЯ ОБЛАСТЬ). СООБЩЕНИЕ 1. ВОДА}

\author{
И. И. Томилина, Р. А. Ложкина, И. В. Чалова, Н. С. Шевченко \\ Институт биологии внутренних вод им. И.Д. Папанина Российской академии наук, \\ 152742 пос. Борок, Ярославская обл., Некоузский p-н, e-mail: i_tomilina@mail.ru
}

Поступила в редакцию 17.07.2020

\begin{abstract}
Впервые проведено исследование токсичности воды высокоэвтрофного оз. Неро с использованием методов биотестирования. За весь период наблюдений по токсикологическим показателям воды к наиболее благополучным относится только ст. 3, расположенная севернее о. Рождественский, на которой не зарегистрирована токсичность ни для одного тест-организма. К наиболее неблагополучным - станции 11, 13 и 16, на которых зарегистрирована токсичность для всех тест-организмов в обе даты наблюдения. На загрязненных участках озера (станции 5-8), приуроченных к его северной части, подверженной воздействию бытовых и промышленных стоков г. Ростова, наблюдали хроническое токсическое действие воды в $80 \%$ случаев. Установлены корреляционные зависимости изменения некоторых тест-функций использованных тест-объектов от содержания в воде отдельных полиароматических углеводородов или их суммы. Мышьяк и нефтепродукты оказывали влияние на рост корней кресс-салата, нефтепродукты на гибель цериодафний за 7 сут и число пометов за этот же срок. Для объективной оценки качества среды необходимо использовать несколько тест-объектов, относящихся к различным систематическим группам и трофическим уровням.
\end{abstract}

Ключевые слова: вода, токсичность, биотестирование, озеро Неро.

DOI: $10.47021 / 0320-3557-2020-87-100$

\section{ВВЕДЕНИЕ}

Несмотря на наметившуюся в последние годы положительную тенденцию уменьшения антропогенной нагрузки на отдельные водные объекты, заметного улучшения качества поверхностных вод не происходит. Максимальному загрязнению подвергаются водоемы в районах с развитым промышленным или сельскохозяйственным производством, а также с выраженной рекреационной нагрузкой. Это происходит, в частности, из-за того, что большинство загрязняющих веществ, поступающих в воздух и почву, в конечном итоге оказываются в водоемах. Особенно важно изучение токсикологической ситуации в водоемах, являющихся источниками питьевого водоснабжения и рекреационными зонами для больших групп населения. К таким водоемам относится оз. Неро [Состояние экосистемы..., 2008 (Sostoyanie ekosistemy..., 2008)].

Озеро Неро - самое крупное озеро Ярославской области, памятник природы, находится в неудовлетворительном экологическом и санитарно-гигиеническом состоянии, но, несмотря на это, широко используется населением в рекреационных целях. Северная часть оз. Неро подвержена сильному антропогенному воздействию бытовых и промышленных стоков г. Ростова и поселков, расположенных по берегам озера, маломерного флота, поверхностного стока с сельскохозяйственных угодий, ферм и крупных автомагистралей [Состояние экосистемы..., 2008 (Sostoyanie ekosistemy..., 2008)].

Токсическое действие вредных веществ на биоту водоемов является одним из главных негативных последствий антропогенного загрязнения природных вод. Качество воды, определяемое с помощью методик биотестирования, принято оценивать, как оказывающее токсическое и/или нетоксическое действие. В мировой практике методам биотестирования (из числа биологических методов) все больше отводится роль скрининга загрязнения, результатом которого является сигнальная информация о местах и степени токсичности воды [Бакаева и др., 2009 (Bakaeva et al., 2009)]. Задачей биотестирования является не идентификация загрязняющих веществ и их концентраций, a экологическая интерпретация воздействия всего комплекса содержащихся в воде веществ на живые организмы.

Токсикологические исследования воды оз. Неро ранее не проводились. Исследовалась только митозмодифицирующая и мутагенная активность воды [Ковалева и др., 2013 (Kovaleva et al., 2013); Шагина и др., 2017 (Shagina et al., 2017)].

Цель работы - оценить токсичность воды оз. Неро методами биотестирования с использованием организмов различной систематической принадлежности. 


\section{МАТЕРИАЛЫ И МЕТОДЫ}

Пробы воды отбирали из поверхностного слоя батометром Рутнера в июне и августе 2017 г. на 20 станциях по сетке, охватывающей всю акваторию озера (рис. 1). Токсичность оценивали в соответствии со стандартными методиками биотестирования с использованием трех тест-объектов: одноклеточной зеленой водоросли Chlorella vulgaris Beijer, 1890; ветвистоусого рачка Ceriodaphnia dubia Richard, 1894 [Определитель зоопланктона..., 2010 (Opredelitel' zooplanktona..., 2010)] и семян кресс-салата Lepidum sativum L., 1753 сорта "Весенний” фирмы Гавриш [Методика определения токсичности..., 2007 (Metodika opredeleniya toksichnosti..., 2007); ГОСТ .., 2012 (GOST, 2012); Методы оценки.., 2014 (Metody ocenki.., 2014); Mount, Norberg, 1984; Методика определения токсичности..., 2007 (Metodika opredeleniya toksichnosti ..., 2007); Фомин, Фомин, 2001 (Fomin, Fomin, 2001; Методика определения токсичности..., 2013 (Metodika opredeleniya toksichnosti..., 2013)] (табл. 1).

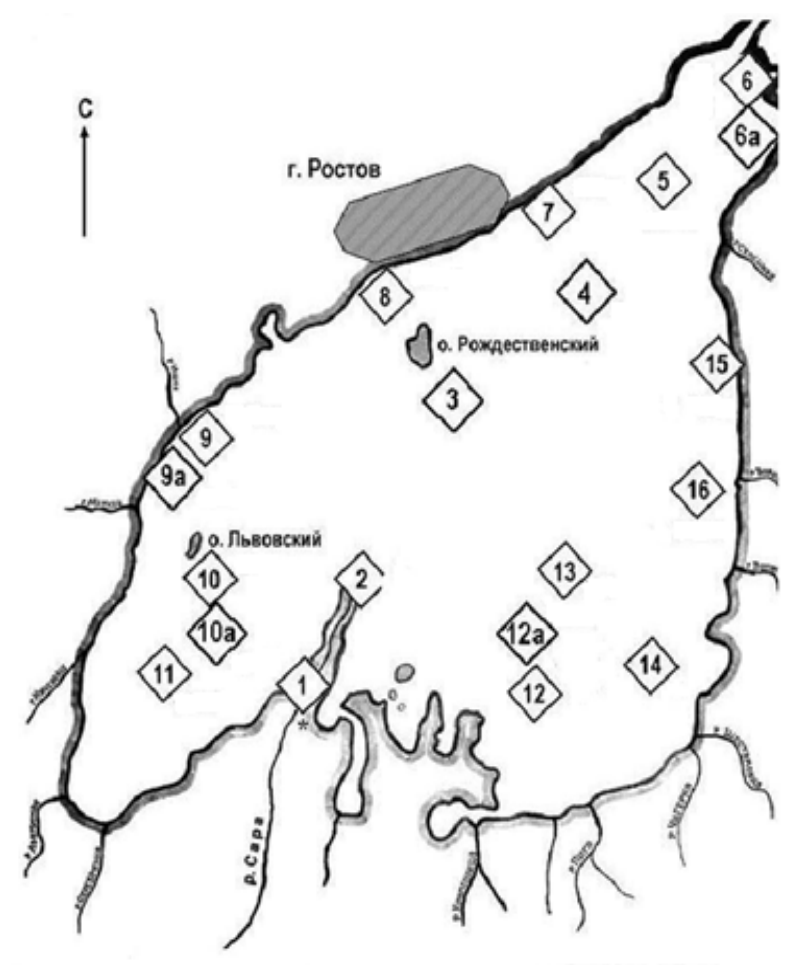

Рис.1. Карта-схема расположения станций отбора проб воды оз. Неро.

1 - p. Сара ниже пос. Поречье-Рыбное; 2 - устье р. Сара; 3 - о. Рождественский; 4 - разрез “Кремль" - с. Угодичи; 5 - против места добычи сапропеля; 6 - исток р. Векса; 6а - урез воды вблизи истока р. Векса; 7 - литораль против предприятия "Рольма"; 8 - литораль против предприятия "Русь-квас"; 9 - против устья р. Ишня; 9а вблизи устья р. Ишня, в 10-15 м от берега; 10 - о. Львовский; 10а - Левский залив; 11 - южная часть Левского залива; 12 - заросшая литораль Воржинского залива; 12a - Воржинский залив, заросли камыша; 126 - Воржинский залив, заросли тростника; 13 - напротив с. Воржа; 14 - заросшая литораль в глубине Воржинского залива; 15 - литоральная зона против с. Угодичи; 16 - литораль против с. Борисовское.

Fig. 1. Map of the location of water sampling stations of Lake Nero.

1 - river Sara below the village Porechye-Rybnoye; 2 - mouth of the river Sara; 3 - island Rozhdestvenskij; 4 - section "Kremlin" - village Ugodichi; 5 - opposite the sapropel extraction site; 6 - the source of the river Veksa; $6 a$ - water edge near the source of the river Veksa; 7 - littoral against the Rolma enterprise; 8 - littoral against the Rus-Kvass enterprise; 9 - opposite the mouth of the river Ishnya; 9a - near the mouth of the river Ishnya, 10-15 $\mathrm{m}$ from the coast;10 - island Lvovskij; 10a - Levsky Bay; 11 - southern part of the Levsky Bay; 12 - overgrown littoral of Vorzhinsky Bay; 12a - Vorzhinsky Bay, thickets of reeds;. 12b - Vorzhinsky Bay, reed thickets; 13 - opposite river Vorzh; 14 - overgrown littoral in the depths of Vorzhinsky Bay; 15 - littoral zone opposite the village Ugodichi; 16 - littoral against village Borisovskoe.

Методика определения токсичности проб воды с использованием хлореллы основана на регистрации изменения темпа роста (снижение или увеличение численности) клеток водорослей под воздействием токсических веществ, присутствующих в тестируемой воде, водной вытяжке из почв, осадков сточных вод, отходов (опыт) по сравнению с культурой в пробах, не содержащих токсических веществ (контроль). 
Труды Института биологии внутренних вод им. И.Д. Папанина РАН, вып. 91(94), 2020 г.

Таблица 1. Критерии оценки токсичности проб воды для тест-объектов, используемых в исследовании

Table 1. Criteria for the assessing of water samples toxicity for test objects used in the study

\begin{tabular}{|c|c|c|c|c|c|c|c|c|}
\hline & & & \multicolumn{6}{|c|}{$\begin{array}{l}\text { Tест-объекты } \\
\text { Test-objects }\end{array}$} \\
\hline \multicolumn{9}{|c|}{$\begin{array}{c}\text { Одноклеточная водоросль Chlorella vulgaris } \\
\text { Single-celled green alga Chlorella vulgaris }\end{array}$} \\
\hline \multicolumn{3}{|c|}{$\begin{array}{l}\text { Стимуляция } \\
\text { Stimulation }\end{array}$} & \multicolumn{6}{|c|}{$\begin{array}{l}\text { Угнетение } \\
\text { Inhibition }\end{array}$} \\
\hline $\begin{array}{l}\text { Оценка токсично- } \\
\text { сти }\end{array}$ & \multirow{2}{*}{\multicolumn{2}{|c|}{$\begin{array}{c}\text { Прирост численности } \\
\text { клеток водорослей } \\
\text { в анализируемой про- } \\
\text { бе относительно кон- } \\
\text { троля, \% }\end{array}$}} & \multicolumn{5}{|c|}{ Оценка токсичности } & $\begin{array}{l}\text { Снижение чис- } \\
\text { ленности клеток }\end{array}$ \\
\hline $\begin{array}{c}\text { Общая } \\
\text { (Методика... } \\
\text { ФР.1.39.2007.03223; } \\
\text { «ГОСТ Р 54496- } \\
\text { 2011) }\end{array}$ & & & \multicolumn{2}{|c|}{$\begin{array}{l}\text { Общая (Методика... } \\
\text { ФР.1.39.2007.03223.., } \\
\text { ГОСТ Р 54496-2011) }\end{array}$} & \multicolumn{3}{|c|}{$\begin{array}{c}\text { Детальная } \\
\text { (Р52.24.809-2014) }\end{array}$} & $\begin{array}{c}\text { водорослей } \\
\text { в анализируемой } \\
\text { пробе относи- } \\
\text { тельно контроля, } \\
\text { \% }\end{array}$ \\
\hline Нетоксичная & \multicolumn{2}{|r|}{ до 30} & \multicolumn{2}{|r|}{ Отсутствует } & \multicolumn{3}{|c|}{ Нетоксичная } & $\begin{array}{c}\text { до } 10 \\
\text { включительно }\end{array}$ \\
\hline \multirow[t]{4}{*}{ Токсичная } & \multirow{4}{*}{\multicolumn{2}{|c|}{$\begin{array}{c}\text { токсичная, если } \\
\text { в хронических опытах } \\
\text { на дафниях или це- } \\
\text { риодафниях отмечено } \\
\text { увеличение плодови- } \\
\text { тости рачков более } \\
\text { чем на } 30 \% \text { или гибель } \\
\text { рачков на } 20 \% \text { и более } \\
\text { по сравнению с кон- } \\
\text { тролем }\end{array}$}} & \multirow{3}{*}{\multicolumn{2}{|c|}{$\begin{array}{c}\text { не оказывает острого } \\
\text { токсического дейст- } \\
\text { вия }\end{array}$}} & \multicolumn{3}{|c|}{ слаботоксичная } & $\begin{array}{c}\text { от } 10 \text { до } 25 \\
\text { включительно }\end{array}$ \\
\hline & & & & & \multicolumn{3}{|c|}{ малотоксичная } & $\begin{array}{c}\text { от } 25 \text { до } 35 \\
\text { включительно }\end{array}$ \\
\hline & & & & & \multicolumn{3}{|c|}{ среднетоксичная } & $\begin{array}{c}\text { от } 35 \text { до } 50 \\
\text { включительно }\end{array}$ \\
\hline & & & \multicolumn{2}{|c|}{$\begin{array}{c}\text { оказывает острое } \\
\text { токсическое дейст- } \\
\text { вие (острая токсич- } \\
\text { ность) } \\
\end{array}$} & \multicolumn{3}{|c|}{ высокотоксичная } & $\begin{array}{l}\text { от } 50 \text { до } 100 \\
\text { включительно }\end{array}$ \\
\hline \multicolumn{9}{|c|}{$\begin{array}{l}\text { Ветвистоусые ракообразные Ceriodaphnia dubia } \\
\text { Cladoceran Ceriodaphnia dubia }\end{array}$} \\
\hline \multirow{2}{*}{\multicolumn{3}{|c|}{ Острое токсическое действие }} & \multicolumn{6}{|c|}{ Хроническое токсическое действие } \\
\hline & & & \multicolumn{3}{|c|}{ Смертность } & \multicolumn{3}{|c|}{ Плодовитость } \\
\hline \multicolumn{3}{|c|}{$\begin{array}{c}\text { Гибель } 50 \% \text { и более цериодафний за } 48 \text { ч } \\
\text { в исследуемой воде при условии, что в кон- } \\
\text { троле гибель не превышает } 10 \%\end{array}$} & \multicolumn{3}{|c|}{$\begin{array}{c}\text { Гибель 20\% и более тест- } \\
\text { организмов за } 7 \text { дней }\end{array}$} & \multicolumn{3}{|c|}{$\begin{array}{c}\text { достоверное снижение репро- } \\
\text { дуктивных показателей живот- } \\
\text { ных за } 7 \text { дней }\end{array}$} \\
\hline \multicolumn{9}{|c|}{$\begin{array}{l}\text { Семена кресс-салата Lepidum sativum } \\
\text { Seeds of watercress Lepidum sativum }\end{array}$} \\
\hline \multicolumn{2}{|l|}{$\begin{array}{l}\text { загрязнение } \\
\text { отсутствует }\end{array}$} & \multicolumn{2}{|c|}{$\begin{array}{c}\text { слабое } \\
\text { загрязнение }\end{array}$} & \multicolumn{3}{|c|}{$\begin{array}{c}\text { среднее } \\
\text { загрязнение }\end{array}$} & \multicolumn{2}{|c|}{$\begin{array}{c}\text { сильное } \\
\text { загрязнение }\end{array}$} \\
\hline \multicolumn{2}{|c|}{$\begin{array}{c}\text { всхожесть семян достигает } \\
\text { 90-100\%, всходы дружные, } \\
\text { проростки крепкие, ровные. } \\
\text { Эти признаки характерны и } \\
\text { для контроля, с которым } \\
\text { следует сравнивать опытные } \\
\text { образцы }\end{array}$} & \multicolumn{2}{|c|}{$\begin{array}{c}\text { всхожесть } 60-90 \%, \\
\text { проростки почти } \\
\text { нормальной длины, } \\
\text { крепкие, ровные }\end{array}$} & \multicolumn{3}{|c|}{$\begin{array}{c}\text { всхожесть 20-60\%, про- } \\
\text { ростки по сравнению } \\
\text { с контролем короче и } \\
\text { тоньше, некоторые из них } \\
\text { имеют уродства }\end{array}$} & \multicolumn{2}{|c|}{$\begin{array}{c}\text { сильное загрязнение: } \\
\text { всхожесть семян очень } \\
\text { слабая (менее 20\%), } \\
\text { проростки мелкие и урод- } \\
\text { ливые }\end{array}$} \\
\hline
\end{tabular}

Показателями токсического действия воды на цериодафний служили смертность и изменения в плодовитости рачков при воздействии загрязняющих веществ, присутствующих в тестируемых пробах, по сравнению с контрольными за 7 сут.

Фитотестирование степени загрязнения природной воды с использованием семян кресс-салата Lepidum sativum основано на изучении показателей прорастания (энергия прорастания за 24 ч, всхожесть за 5 сут экспозиции) и интенсивности начального роста семян (длина корня и побега, мм) за 5 сут по сравнению с контролем. Методику дополнили разработками В.П. Лебедева [Лебедев, 2006 (Lebedev, 2006)].

Биотестирование проводили в лабораторных условиях в соответствии с требованиями соответствующих методик.

Результаты обрабатывали статистически и представляли в виде средних значений и их ошибок $(\mathrm{x} \pm \mathrm{mx})$. Достоверность различий оценивали методом дисперсионного анализа (ANOVA, LSD-тест) при уровне значимости $p \leq 0.05$ [Sokal, Rohlf, 1995]. 


\section{РЕЗУЛЬТАТЫ ИССЛЕДОВАНИЯ И ИХ ОБСУЖДЕНИЕ}

При определении степени токсичности воды оз. Неро, отобранной в июне 2017 г., с использованием цериодафний, установлено, что вода ни на одной из станций не оказывала острого токсического действия на рачков, то есть не наблюдали $50 \%$ и выше смертности рачков (табл. 2). Вода, отобранная на станциях 5, 6 и 10а оказывала хроническое токсическое действие по показателю “выживаемость”, то есть зафиксирована гибель рачков, превышающая допустимый методикой $20 \%$ уровень за 7 сут экспозиции. По показателю “плодовитость” хроническое токсическое действие зарегистрировано на станциях $5,6,7-11,12 \mathrm{a}, 13$, 15 и 16 . Вода, отобранная на станциях $7,8,9$, 10 и 11, оказывала стимулирующее действие, увеличивала среднее количество молоди на 1 самку на $38-121 \%$, на станциях $6,9 \mathrm{a}, 10 \mathrm{a}$, $12 \mathrm{a}, 13,15$ и 16 - подавляла размножение рачков на $50-70 \%$ (табл. 2).

Таким образом, к нетоксичным пробам относится вода, отобранная на станциях $1,2,3$, 4, 6а, 12 и 14, остальные - к оказывающее хроническое токсическое действие на ветвистоусых ракообразных.

При биотестировании воды с использованием одноклеточных водорослей Chlorella vulgaris установлено, что снижение роста численности её клеток отмечено только на ст. 12 и составило 5\% по сравнению с контролем, что не является токсическим эффектом (табл. 3).

К воде, не оказывающей токсического действия на одноклеточные водоросли, можно отнести пробы, отобранные на станциях 2 и 3 прирост клеток хлореллы не превышал 11\% по сравнению с контролем. Несмотря на то, что вода со станций 1,4 и 14а вызывала стимуляцию роста клеток хлореллы от 30 до $35 \%$, ее можно отнести к не оказывающей токсического действия на одноклеточные водоросли, т.к. при биотестировании этих проб на цериодафниях не отмечено ни гибели рачков, ни достоверных изменений в их плодовитости. Стимулирующий эффект, зарегистрированный при тестировании воды со станций $6 а$ и $8(+34$ и $+75 \%$ соответственно), согласно критериям методики [Методика определения токсичности..., 2007 (Metodika opredeleniya toksichnosti..., 2007)] может быть оценен как токсический, так как в хронических опытах на цериодафниях в воде, отобранной на ст. 6а, зафиксирована гибель $20 \%$ рачков и увеличение их плодовитости на $38 \%$.

Результаты, полученные при тестировании остальных проб воды сложно оценить однозначно в соответствии с критериями методики.

Воду со станций 9а, 12а и 15, вызывающую стимуляцию роста хлореллы от 30 до 43\% по сравнению с контролем, нужно рассматривать как не оказывающую токсического действия, так как в хронических опытах на цериодафниях в этих пробах воды не выявлены ни гибель рачков, превышающая допустимый для контроля 10\% порог, ни стимуляция их плодовитости. Однако в опытах на рачках, экспонированных в воде с этих станций, отмечено достоверное снижение их плодовитости на 57, 42 и 44\% по сравнению с контролем, что позволяет отнести эти пробы к токсичным.

В пробах воды со станций 5, 6, 13 зафиксирован самый незначительный стимулирующий эффект роста клеток хлореллы по сравнению с контролем $(+5-+6 \%)$, который в соответствии с критериями методики позволяет говорить об отсутствии токсического действия. Однако в этих пробах при биотестировании на цериодафниях отмечена самая большая гибель рачков (20-40\%) и снижение их плодовитости на 33-69\% по сравнению с контролем, что позволяет отнести эти пробы к токсичным. В воде со станций $7,9,10,10 \mathrm{a}, 11,16$ стимуляция роста клеток хлореллы была выше и составила 16-26\%, что так же позволяет оценить эту воду как не токсичную для одноклеточных водорослей. Однако в воде, отобранной на станциях 7 и 9, зафиксирована самая большая стимуляция плодовитости цериодафний (95 и 121\% по сравнению с контролем соответственно). Вода со станций 10 и 11 так же вызывала стимуляцию роста клеток водорослей и увеличение плодовитости рачков на 36 и 38\%, что можно рассматривать как токсический эффект. В воде со станций 10а и 16 прирост численности клеток хлореллы еще более выраженный - 22 и 26\%, при этом в этих пробах отмечено достоверное по сравнению с контролем снижение плодовитости цериодафний на 82 и 50\% по сравнению с контролем.

На основании результатов определения степени токсичности воды 03. Неро с помощью одноклеточных водорослей исследованные пробы можно оценить следующим образом: не токсичные пробы - вода со станций $1,2,3$, 4, 12.14, высокотоксичные пробы - вода со станций 6а и 8. Все остальные пробы относятся к оказывающим токсический эффект с разной степенью его выраженности $-5,6,7$, 9, 9a, 10, 10a, 11, 13, 15, 16 . 
Труды Института биологии внутренних вод им. И.Д. Папанина РАН, вып. 91(94), 2020 г.

Таблица 2. Действие природной воды оз. Неро на Ceriodaphnia dubia (июнь 2017 г.)

Table 2. Effect of natural water of Lake Nero for Ceriodaphnia dubia (june 2017)

\begin{tabular}{|c|c|c|c|c|c|}
\hline $\begin{array}{c}\text { Станция } \\
\text { Station }\end{array}$ & $\begin{array}{c}\text { Гибель, \%, } \\
48 \text { час } \\
\text { Mortality, \%, } \\
48 \text { h }\end{array}$ & $\begin{array}{c}\text { Гибель, \%, } \\
7 \text { сут } \\
\text { Mortality, \%, } \\
8 \text { days }\end{array}$ & $\begin{array}{c}\text { Среднее число } \\
\text { пометов } \\
\text { Average } \\
\text { broods }\end{array}$ & $\begin{array}{c}\text { Среднее кол-во молоди на } \\
\frac{1 \text { самку, экз }}{\% \text { контроля }} \\
\text { Average of juveniles } \\
\frac{\text { per female }}{\% \text { control }}\end{array}$ & $\begin{array}{c}\text { Токсичность } \\
\text { пробы } \\
\text { Samples toxicity }\end{array}$ \\
\hline 1 & 0 & 10 & 2.0 & $\frac{12.4 \pm 1.87}{74}$ & HT \\
\hline 2 & 0 & 0 & 2.8 & $\frac{16.8 \pm 2.23}{0}$ & HT \\
\hline 3 & 0 & 10 & 2.5 & $\frac{14.6 \pm 2.24}{87}$ & HT \\
\hline 4 & 0 & 0 & 2.5 & $\frac{14.8 \pm 2.72}{88}$ & HT \\
\hline 5 & 0 & 30 & 2.0 & $\frac{11.3 \pm 1.64}{67}$ & ХТД \\
\hline 6 & 10 & 40 & $1.67^{*}$ & $\frac{5.1 \pm 1.37^{*}}{31}$ & ХТД \\
\hline $6 a$ & 0 & 20 & 1.7 & $\frac{15.1 \pm 2.08}{90}$ & HT \\
\hline 7 & 0 & 0 & $3.0 * *$ & $\frac{32.8 \pm 2.94 * *}{195}$ & ХТД \\
\hline 8 & 0 & 0 & $2.9 * *$ & $\frac{23.2 \pm 3.17^{* *}}{138}$ & ХТД \\
\hline 9 & 0 & 0 & $2.9 * *$ & $\frac{37.2 \pm 3.42 * *}{221}$ & ХТД \\
\hline $9 a$ & 0 & 10 & $1.3 *$ & $\frac{7.3 \pm 1.76^{*}}{43}$ & ХТД \\
\hline 10 & 0 & 0 & $3.1 * *$ & $\frac{22.9 \pm 1.91 * *}{136}$ & ХТД \\
\hline $10 \mathrm{a}$ & 0 & 30 & $1.4^{*}$ & $\frac{3.1 \pm 1.01^{*}}{18}$ & ХТД \\
\hline 11 & 0 & 10 & $2.7 * *$ & $\frac{23.2 \pm 3.09 * *}{138}$ & ХТД \\
\hline 12 & 0 & 10 & 2.22 & $\frac{16.5 \pm 1.66}{98}$ & HT \\
\hline $12 \mathrm{a}$ & 0 & 0 & $1.8^{*}$ & $\frac{9.8 \pm 1.64 *}{58}$ & ХТД \\
\hline 13 & 0 & 20 & $1.8^{*}$ & $\frac{6.8 \pm 1.55^{*}}{40}$ & ХТД \\
\hline 14 & 0 & 0 & 2.3 & $\frac{13.2 \pm 2.18}{79}$ & HT \\
\hline 15 & 0 & 10 & $1.6^{*}$ & $\frac{9.4 \pm 2.61 *}{56}$ & ХТД \\
\hline 16 & 0 & 10 & $1.9^{*}$ & $\frac{8.4 \pm 1.62 *}{50}$ & ХТД \\
\hline $\begin{array}{c}\text { Контроль } \\
\text { Control }\end{array}$ & 0 & 0 & 2.4 & $\frac{16.8 \pm 0.97}{100}$ & \\
\hline
\end{tabular}

Примечание. Здесь и в табл. 4-6 “*”- значение, достоверно ниже контрольного при $p=0.05$, “**” - достоверно выше контрольного значения при $p=0.05$, НТ - отсутствие токсичности, ХТД - хроническое токсическое действие.

Note. Here and in table 4-6 “*” - value significantly lower than the control value at $p=0.05$, “**” - significantly higher than the control value at $p=0.05, \mathrm{NT}-$ no toxicity, CTD - chronic toxic effect. 
Таблица 3. Действие природной воды оз. Неро на Chlorella vulgaris (июнь 2017 г.)

Table 3. Effect of natural water of lake Nero for Chlorella vulgaris (june 2017)

\begin{tabular}{c|c|c}
\hline $\begin{array}{c}\text { Станция } \\
\text { Station }\end{array}$ & $\begin{array}{c}\text { Выявленный } \\
\text { эффект, \% } \\
\text { Detected effect, } \%\end{array}$ & $\begin{array}{c}\text { Токсичность } \\
\text { пробы } \\
\text { Samples toxicity }\end{array}$ \\
\hline 1 & +35 & НТ \\
2 & +7 & HТ \\
3 & +11 & НТ \\
4 & +30 & НТ \\
5 & +5 & ХТД \\
6 & +6 & ХТД \\
$6 \mathrm{a}$ & +34 & ХТД \\
7 & +17 & ХТД \\
8 & +75 & ХТД \\
9 & +16 & ХТД \\
$9 \mathrm{a}$ & +43 & ХТД \\
10 & +26 & ХТД \\
$10 \mathrm{a}$ & +22 & ХТД \\
11 & +10 & ХТД \\
12 & -5 & НТ \\
$12 \mathrm{a}$ & +37 & ХТД \\
13 & +6 & ХТД \\
14 & +35 & НТ \\
15 & +30 & ХТД \\
16 & +26 & ХТД \\
\hline Контроль & Дистиллированная вода \\
Соntrol & \multicolumn{2}{|c}{ Distilled жаter } \\
\hline
\end{tabular}

Примечание. “+”- стимуляция; “_”- -угнетение.

Note. "+" - stimulation; "-_" - inhibition.

В биотестах на семенах кресс-салата Lepidum sativum установлено, что при одинаково высокой всхожести максимальная энергия прорастания наблюдалась в воде, отобранной на ст. 4 (табл. 4), в контроле - 55\%. Минимальная энергия прорастания семян отмечена в воде на ст. 1 (на 75\% ниже, чем в контроле), минимальная всхожесть семян -78.3\% (96.7\% в контроле) зарегистрирована на ст. 13. По всхожести семян воду, отобранную на станциях 1, 11, 12 а и 13 , можно отнести к слабозагрязненной.

Анализ средних значений длин побегов выявил их достоверное снижение по сравнению с контрольными в воде, отобранной на станциях 1 и 19 (на 40\%). Пробы воды со станций 4, 6, 7, 8, 9a, 11 и 16 оказывали стимулирующее действие на длину побега. Поскольку стимуляция была выше, чем 30\%, воду отнесли к оказывающей хроническое токсическое действие. Максимальное значение длины побега зарегистрировано на ст. 6, на 74\% выше контрольного значения.

Статистически значимое угнетение прироста длины корня зарегистрировано в пробах воды со станций $1,5,10 \mathrm{a}, 12 \mathrm{a}$ и $19 \mathrm{a}$, снижение составляло 40-50\%. В воде со станций 4, 6, 11 отмечена стимуляция роста корней салата. При этом увеличение длины корня более 30\% зафиксировано только в пробе со ст. 4, в ней же выявлена и максимальная длина корня - 120 мм (табл. 4).

Сравнивая результаты биотестирования воды, выполненного в июне 2017 г. с использованием 3 тест-объектов, можно заключить, что к наиболее благополучным по токсикологическим показателям относятся станции 2, 3, 12 и 14, на которых не зарегистрирована токсичность ни по одному тест-организму, к наиболее неблагополучным - 5-8, 9a, 10a, 11, 12a, 13, 15 и 16, на которых зарегистрирована токсичность для всех трех тест-организмов (табл. 8). Следует отметить, что большинство этих станций находились вблизи места добычи сапропеля (ст. 5), населенных пунктов (станции $13,15,16)$, в зоне выпуска сточных вод предприятий “Рольма" и “Русь-квас" (станции 7,8$)$, а также в зарослях макрофитов (станции 9а, 10a, 11, 12a).

В августе 2017 г. биотестирование воды о3. Неро с использованием цериодафнии в качестве тест-объекта подтвердило отсутствие острого токсического действия воды озера, отобранной по всей сетке станций, для ракообразных (табл. 5). Несмотря на то, что по показателю “выживаемость" хроническое токсическое действие оказывала только вода с одной ст. 13, возросло количество станций вода с которых, оказывала хроническое токсическое действие по показателю “плодовитость" (4-7, 9-16). В этот ряд попали станции, на которых ранее не было установлено хронического токсического действия на цериодафний ни по одному из показателей $(4,6 a, 12,14)$. Таким образом, в августе 2017 г. из 7 чистых станций по данным 7-суточного теста на цериодафниях в июне 2017 г. (1-4, 6а, 12, 14) осталось только $4(1-3,8)$.

При биотестировании воды оз. Неро на семенах кресс-салата Lepidum sativum установлено, что при одинаково высокой всхожести максимальная энергия прорастания наблюдалась в воде, отобранной на ст. 5 (табл. 6), в контроле - 76.7\%. Минимальная энергия прорастания семян отмечена в воде на ст. 11 (на 40\% ниже, чем в контроле), минимальная всхожесть семян - $85 \%$ зарегистрирована на ст. 7. По всхожести семян воду, отобранную на станциях 7, 10, 11 и 16, можно отнести к слабозагрязненной [Лебедев, 2006 (Lebedev, 2006)].

Анализ средних значений длин побегов показал, что эти показатели достоверно ниже контрольных при биотестировании воды, отобранной на станциях 2, 10-14 и 16 (на 20-30\%). 
Труды Института биологии внутренних вод им. И.Д. Папанина РАН, вып. 91(94), 2020 г.

Статистически значимое подавление роста корней зарегистрировано на станциях 1, 2, 4, 10-14, снижение составляло 30-60\% (табл. 6). Максимальная длина побега отмечена на ст. 7, корня на ст. 15 . На ст. 14 отмечено максимальное число недоразвитых проростков.

Таким образом, к нетоксичным пробам относятся станции $3,5-9$ и 15 , остальные пробы обладают в той или иной степени фитотоксическим эффектом.

К наиболее благополучным станциям по токсикологическим показателям воды, отобранной в августе 2017 г., относится только ст. 3, на которой не зарегистрирована токсичность ни по одному тест-организму. К наиболее неблагополучным - 4, 14, 15 и 16, на которых зарегистрирована токсичность по двум тест-организмам.

В нашем исследовании доля станций, на которых зафиксирована хроническая токсичность воды для ветвистоусых рачков в июне 2017 г. составляла $65 \%$, в августе - 60\%, для семян кресс-салата $65 \%$ и $56.3 \%$ соответственно. Биотестирование воды с использованием водоросли Chlorella vulgaris проводили однократно, и доля станций с обнаруженной хронической токсичностью составила $70 \%$.

Таким образом, пробы воды, отобранные и в июне, и в августе обладали одинаковой токсичностью для тест-организмов (табл. 7).

Природные воды являются весьма специфической средой, в которой состояние токсикантов и проявление их химических свойств и биологической активности существенно отличается от более простых экспериментальных моделей, на которых обычно проводятся лабораторные исследования их химических, биологических, токсических и других свойств [Александрова, 2009 (Aleksandrova, 2009)]. Нормальная жизнедеятельность гидробионтов, a, следовательно, и уровень их устойчивости к различным повреждающим агентам, в частности, к токсическим веществам, а также степень токсичности различных групп веществ в значительной степени определяются такими абиотическими факторами водной среды, как минерализация, жесткость, $\mathrm{pH}$, соотношение ионов, наличие комплексонов, содержание кислорода, температура и т.д.

Биотестирование, как правило, проводится в стандартных, оптимальных для тестобъектах условиях; в частности, при биотестировании редко принимается во внимание температурный фактор, существенно влияющий на результаты биотестов [Брагинский и др., 1987 (Braginskij et al., 1987)]. Косвенным подтверждением этого могут служить и результа- ты наших исследований. Так, пробы воды, отобранные в июне 2017 г., когда температура поверхностного слоя колебалась от 17.1 до $19.0^{\circ} \mathrm{C}$, обладали большей токсичностью для всех 3-х тест-объектов, чем пробы воды, отобранные в августе 2017 г., при температуре воды $21.6-23.9^{\circ} \mathrm{C}$. С этим может быть связано и повышение более чем на $30 \%$ плодовитости цериодафний в августе.

Интерпретация результатов токсикологических опытов по критерию выживаемости более проста в сравнении с интерпретацией результатов по критерию плодовитости. Известно, что наиболее значительно повышается плодовитость ветвистоусых рачков в летний период в июле, что связано, вероятнее всего, с самой высокой солнечной активностью в данный период.

По критерию выживаемость хроническим токсическим действием обладала вода, отобранная в июне на станциях 5,6 и 10a, в августе - только на ст. 13. По критерию плодовитость большее число станций отнесено к неблагополучным. Как в июне, так и в августе таких станций насчитывалось 12. Если в июне на 7 из 12 проб воды, отобранных на станциях, где зарегистрировано хроническое токсическое действие на цериодафний, отмечено снижение репродуктивных показателей рачков, то в августе на всех 12 станциях отмечено повышение их плодовитости. Что может быть связано не только с повышением температуры и изменением солнечной активности в этот период, но и с благоприятным микроклиматом, a также с интенсификацией процессов самоочищения в водном объекте.

В некоторых работах затрагивается вопрос о критериях токсичности по показателям стимуляции тест-функции [Некрасова., 2008 (Nekrasova, 2008)]. Заключение о токсичности тестируемой среды как в случае угнетения роста культуры (на 20\% по сравнению с контролем), так и при его стимуляции (на 30\%) предусматривает только методика с использованием хлореллы [Методика..., 2007 (Metodika..., 2007)]. Очевидно, что игнорировать эффекты стимуляции тест-функций нельзя. Стимуляция может проявляться как фаза интоксикации или как отклик на факторы, повышающие метаболические процессы: присутствие в исследуемых средах окисляемых органических или биогенных веществ, витаминов, гормонов, биостимуляторов. То есть не всегда стимуляция является откликом на токсичность. При этом возникает сложность интерпретации полученных данных, с целью определения причин стимулирующего эффекта. 
Таблица 4. Действие природной воды оз. Неро на семена кресс-салата Lepidum sativum (июнь 2017 г.)

Table 4. Effect of natural water of Lake Nero for the seeds of watercress Lepidum sativum (june 2017)

\begin{tabular}{|c|c|c|c|c|c|c|c|}
\hline $\begin{array}{l}\text { Станция } \\
\text { Station }\end{array}$ & $\begin{array}{c}\text { Энергия прорастания, \% } \\
\text { Germination energy,\% }\end{array}$ & $\begin{array}{c}\text { Всхожесть, \% } \\
\text { Germination, \% }\end{array}$ & $\begin{array}{l}\text { Средняя длина } \\
\text { проростка, мм } \\
\text { Average length } \\
\text { of seedling, mm }\end{array}$ & $\begin{array}{c}\text { Средняя длина } \\
\text { побега, мм } \\
\text { Average length } \\
\text { of shoot, mm }\end{array}$ & $\begin{array}{l}\text { Средняя длина } \\
\text { корня, мм } \\
\text { Average length } \\
\text { of root, mm } \\
\end{array}$ & $\begin{array}{c}\text { Соотношение } \\
\text { побег / корень } \\
\text { Ratio } \\
\text { shoot / root } \\
\end{array}$ & $\begin{array}{c}\text { Токсичность } \\
\text { пробы } \\
\text { Samples } \\
\text { toxicity }\end{array}$ \\
\hline 1 & 13.3 & 86.7 & $7.96 \pm 0.89 *$ & $7.96 \pm 0.89^{*}$ & $20.40 \pm 21.41^{*}$ & $0.51 \pm 0.09$ & ХТД \\
\hline 2 & 78.3 & 93.3 & $12.79 \pm 1.11$ & $12.79 \pm 1.11$ & $37.57 \pm 3.44$ & $0.46 \pm 0.07$ & HT \\
\hline 3 & 58.3 & 95.0 & $11.32 \pm 1.06$ & $11.32 \pm 1.06$ & $28.21 \pm 2.96$ & $0.50 \pm 0.06$ & HT \\
\hline 4 & 98.4 & 98.4 & $20.15 \pm 1.32^{* *}$ & $20.15 \pm 1.32 * *$ & $56.37 \pm 3.91 * *$ & $0.41 \pm 0.04$ & ХТД \\
\hline 5 & 66.7 & 95.0 & $15.40 \pm 1.15$ & $15.40 \pm 1.15$ & $27.93 \pm 2.60 *$ & $0.58 \pm 0.04$ & ХТД \\
\hline 6 & 93.3 & 96.7 & $23.03 \pm 1.48 * *$ & $23.03 \pm 1.48^{* *}$ & $48.02 \pm 3.48 * *$ & $0.48 \pm 0.02$ & ХТД \\
\hline $6 a$ & 64.4 & 96.6 & $12.65 \pm 0.97$ & $12.65 \pm 0.97$ & $33.16 \pm 2.64$ & $0.49 \pm 0.07$ & HT \\
\hline 7 & 73.3 & 93.3 & $20.64 \pm 1.64 * *$ & $20.64 \pm 1.64 * *$ & $44.39 \pm 3.88$ & $0.47 \pm 0.02$ & ХТД \\
\hline 8 & 76.7 & 95.0 & $18.35 \pm 1.62^{* *}$ & $18.35 \pm 1.62 * *$ & $40.72 \pm 3.66$ & $0.44 \pm 0.03$ & ХТД \\
\hline 9 & 58.3 & 95.0 & $15.72 \pm 1.66$ & $15.72 \pm 1.66$ & $33.25 \pm 3.66$ & $0.50 \pm 0.09$ & $\mathrm{HT}$ \\
\hline $9 a$ & 60.0 & 91.7 & $19.95 \pm 1.73 * *$ & $19.95 \pm 1.73 * *$ & $40.85 \pm 3.9$ & $0.55 \pm 0.09$ & ХТД \\
\hline 10 & 74.2 & 96.8 & $15.47 \pm 1.25$ & $15.47 \pm 1.25$ & $44.05 \pm 3.53$ & $0.36 \pm 0.02$ & HT \\
\hline $10 \mathrm{a}$ & 53.3 & 93.3 & $11.0 \pm 1.36$ & $11.0 \pm 1.36$ & $23.07 \pm 2.33^{*}$ & $0.44 \pm 0.08$ & ХТД \\
\hline 11 & 66.1 & 89.8 & $22.55 \pm 1.82 * *$ & $22.55 \pm 1.82 * *$ & $48.47 \pm 3.95^{* *}$ & $0.45 \pm 0.05$ & ХТД \\
\hline 12 & 60.3 & 96.6 & $13.11 \pm 1.21$ & $13.11 \pm 1.21$ & $32.56 \pm 2.94$ & $0.74 \pm 0.23 * *$ & HT \\
\hline $12 \mathrm{a}$ & 65.0 & 83.3 & $12.78 \pm 1.73$ & $12.78 \pm 1.73$ & $23.64 \pm 3.01 *$ & $0.46 \pm 0.06$ & ХТД \\
\hline 13 & 48.3 & 78.3 & $12.81 \pm 2.00$ & $12.81 \pm 2.00$ & $28.0 \pm 4.18^{*}$ & $0.40 \pm 0.09$ & ХТД \\
\hline 14 & 65.0 & 90.0 & $14.11 \pm 1.74$ & $14.11 \pm 1.74$ & $32.87 \pm 4.02$ & $0.40 \pm 0.05$ & HT \\
\hline 15 & 51.7 & 91.7 & $8.31 \pm 1.15^{*}$ & $8.31 \pm 1.15^{*}$ & $18.25 \pm 2.09^{*}$ & $0.34 \pm 0.05$ & ХТД \\
\hline 16 & 87.9 & 100.0 & $18.41 \pm 1.38^{* *}$ & $18.41 \pm 1.38^{* *}$ & $41.05 \pm 3.08$ & $0.50 \pm 0.04$ & ХТД \\
\hline $\begin{array}{c}\text { Контроль } \\
\text { Control }\end{array}$ & 55.0 & 96.7 & $13.21 \pm 1.07$ & $13.21 \pm 1.07$ & $38.29 \pm 3.35$ & $0.44 \pm 0.06$ & \\
\hline
\end{tabular}


Таблица 5. Действие природной воды оз. Неро на Ceriodaphnia dubia (август 2017 г.)

Table 5. Effect of natural water of lake Nero for Ceriodaphnia dubia (august 2017)

\begin{tabular}{|c|c|c|c|c|c|}
\hline $\begin{array}{c}\text { Станция } \\
\text { Station }\end{array}$ & $\begin{array}{c}\text { Гибель, \%, } 48 \text { ч } \\
\text { Mortality, \%, } \\
48 \text { h }\end{array}$ & $\begin{array}{c}\text { Гибель, \%, } 7 \text { сут } \\
\text { Mortality, \%, } \\
8 \text { days }\end{array}$ & $\begin{array}{c}\text { Среднее число } \\
\text { пометов } \\
\text { Average } \\
\text { broods }\end{array}$ & $\begin{array}{c}\text { Среднее кол-во молоди на } \\
\frac{1 \text { самку, экз }}{\% \text { контроля }} \\
\text { Average of juvenile } \\
\text { per female } \\
\% \text { control }\end{array}$ & $\begin{array}{c}\text { Токсичность } \\
\text { пробы } \\
\text { Samples toxicity }\end{array}$ \\
\hline 1 & 0 & 0 & 2.4 & $\frac{20.9 \pm 2.74}{140.3}$ & HT \\
\hline 2 & 0 & 10 & 2.3 & $\frac{18.7 \pm 2.51}{125.5}$ & HT \\
\hline 3 & 0 & 0 & 2.5 & $\frac{20.3 \pm 2.03}{136.2}$ & HT \\
\hline 4 & 0 & 0 & 2.6 & $\frac{25.6 \pm 1.67 * *}{171.8}$ & ХТД \\
\hline 5 & 0 & 0 & 2.5 & $\frac{27.9 \pm 3.03^{* *}}{187.2}$ & ХТД \\
\hline 6 & 0 & 0 & 2.9 & $\frac{32.4 \pm 1.59 * *}{217.4}$ & ХТД \\
\hline 7 & 0 & 0 & 2.6 & $\frac{32.1 \pm 3.29 * *}{219.7}$ & ХТД \\
\hline 8 & 0 & 0 & 2.3 & $\frac{21.4 \pm 2.28}{143.6}$ & HT \\
\hline 9 & 0 & 0 & 2.7 & $\frac{29.1 \pm 3.95^{* *}}{195.3}$ & ХТД \\
\hline 10 & 20 & 20 & 2.2 & $\frac{30.9 \pm 1.85^{* *}}{207.4}$ & ХТД \\
\hline 11 & 0 & 0 & 2.9 & $\frac{30.8 \pm 3.23^{* *}}{206.7}$ & ХТД \\
\hline 12 & 0 & 0 & 2.8 & $\frac{26.7 \pm 3.16^{* *}}{179.2}$ & ХТД \\
\hline 13 & 20 & 30 & 2.0 & $\frac{28.6 \pm 4.20 * *}{191.9}$ & ХТД \\
\hline 14 & 0 & 0 & 2.8 & $\frac{26.0 \pm 2.80^{* *}}{174.5}$ & ХТД \\
\hline 15 & 0 & 0 & 2.9 & $\frac{30.0 \pm 1.45^{* *}}{201.3}$ & ХТД \\
\hline 16 & 0 & 0 & 2.9 & $\frac{28.9 \pm 2.48^{* *}}{193.9}$ & ХТД \\
\hline $\begin{array}{c}\text { Контроль } \\
\text { Control }\end{array}$ & 0 & 0 & 3.0 & $\frac{14.9 \pm 1.84}{100}$ & \\
\hline
\end{tabular}

С одной стороны, необходимо выявить стимулирующее действие токсикантов, с другой - исключить стимуляцию за счет дополнительных источников питания [Жмур, 2018 (Zhmur, 2018)]. Стимулирующее влияние токсиканта на процесс размножения гидробионтов может отражать неблагополучное состояние популяции, стремящийся к сохранению вида в экстремальных условиях существования [Веселов, 1977 (Veselov, 1977)].

Метод биотестирования, основанный на реакции набора тест-объектов, даёт интегральную оценку вреда, вызываемого суммарным токсическим действием всего комплекса загрязняющих веществ, содержащихся в водной среде, с учетом их синергизма и антагонизма. Как правило, биотестирование не дает ответа на вопрос о характере загрязняющего вещества, вызывавшего ту или иную реакцию тест-объекта [Крайнюкова, 1988 (Krainyukova, 1988)].

Для оценки возможной зависимости токсических эффектов от содержания загрязняющих веществ в воде необходимо знать параметры гидрохимического состава вод. Исследование показало, что концентрации хрома, цинка, кадмия, мышьяка, ртути и свинца на всех станциях не превышают значений ПДК для водных объектов рыбохозяйственного назначения и для хозяйственно-питьевого и культурно-бытового водопользования [Чуйко и др., 2020 (Chuyko et al., 2020)]. 
Таблица 6. Действие природной воды оз. Неро на семена кресс-салата (август 2017 г.)

Table 6. Effect of natural water Lake Nero for watercress seeds (august 2017)

\begin{tabular}{|c|c|c|c|c|c|c|c|c|}
\hline $\begin{array}{c}\text { Станция } \\
\text { Station }\end{array}$ & $\begin{array}{c}\text { Энергия прорастания, \% } \\
\text { Germination energy,\% }\end{array}$ & $\begin{array}{l}\text { Всхожесть, \% } \\
\text { Germination, \% }\end{array}$ & $\begin{array}{l}\text { Средняя длина } \\
\text { проростка, мм } \\
\text { Average length } \\
\text { of seedling, mm }\end{array}$ & $\begin{array}{c}\text { Средняя длина } \\
\text { побега,мм } \\
\text { Average length } \\
\text { of shoot, mm }\end{array}$ & $\begin{array}{c}\text { Средняя длина } \\
\text { корня, мм } \\
\text { Average length } \\
\text { of root, mm }\end{array}$ & $\begin{array}{c}\text { Соотношение } \\
\text { побег/корень } \\
\text { Ratio } \\
\text { shoot / root } \\
\end{array}$ & $\begin{array}{c}\text { \% недоразвитых } \\
\text { проростков } \\
\text { \% underdeveloped } \\
\text { seedlings }\end{array}$ & $\begin{array}{c}\text { Токсичность } \\
\text { пробы } \\
\text { Samples toxicity }\end{array}$ \\
\hline 1 & 66.7 & 93.3 & $39.2 \pm 3 ю 13$ & $19.1 \pm 10.91$ & $39.2 \pm 3.13^{*}$ & $0.5 \pm 0.05$ & 1.67 & ХТД \\
\hline 2 & 63.3 & 95.0 & $34.67 \pm 3.15^{*}$ & $15.3 \pm 1.37 *$ & $34.7 \pm 3.15^{*}$ & $0.4 \pm 0.05$ & 3.33 & ХТД \\
\hline 3 & 80.0 & 90.0 & $49.65 \pm 3.48$ & $20.4 \pm 1.38$ & $49.6 \pm 3.48$ & $0.5 \pm 0.10$ & 5.00 & HT \\
\hline 4 & 86.7 & 93.3 & $36.14 \pm 2.88 *$ & $18.1 \pm 1.35$ & $36.1 \pm 2.88 *$ & $0.6 \pm 0.07$ & 1.67 & ХТД \\
\hline 5 & 96.7 & 98.3 & $48.73 \pm 3.87$ & $21.6 \pm 1.60$ & $48.7 \pm 3.87$ & $0.5 \pm 0.04$ & 3.33 & HT \\
\hline 6 & 91.7 & 95.0 & $46.81 \pm 2.97$ & $20.7 \pm 1.12$ & $46.8 \pm 2.97$ & $0.8 \pm 0.28$ & 1.67 & HT \\
\hline 7 & 75.0 & 85.0 & $43.69 \pm 3.12$ & $22.4 \pm 1.59$ & $43.7 \pm 3.12$ & $0.5 \pm 0.03$ & 0 & HT \\
\hline 8 & 83.3 & 93.3 & $48.09 \pm 2.73$ & $22.3 \pm 1.15$ & $48.1 \pm 2.73$ & $0.5 \pm 0.03$ & 0 & HT \\
\hline 9 & 83.3 & 95.0 & $42.19 \pm 2.97$ & $19.0 \pm 1.34$ & $42.2 \pm 2.97$ & $0.5 \pm 0.06$ & 0 & HT \\
\hline 10 & 56.7 & 88.3 & $36.51 \pm 3.49 *$ & $16.1 \pm 1.57^{*}$ & $36.5 \pm 3.49 *$ & $0.4 \pm 0.04$ & 0 & ХТД \\
\hline 11 & 46.7 & 86.6 & $20.65 \pm 2.99 *$ & $8.4 \pm 1.10^{*}$ & $20.6 \pm 2.99 *$ & $0.6 \pm 0.12$ & 0 & ХТД \\
\hline 12 & 78.3 & 98.3 & $37.84 \pm 3.59^{*}$ & $15.7 \pm 1.40^{*}$ & $37.8 \pm 3.59 *$ & $0.5 \pm 0.06$ & 1.67 & ХТД \\
\hline 13 & 70.0 & 93.3 & $37.45 \pm 3.50 *$ & $16.1 \pm 1.47 *$ & $37.5 \pm 3.50 *$ & $0.5 \pm 0.06$ & 0 & ХТД \\
\hline 14 & 81.7 & 96.7 & $40.40 \pm 3.83$ & $16.8 \pm 1.49^{*}$ & $40.4 \pm 3.83^{*}$ & $0.6 \pm 0.14$ & 6.67 & ХТД \\
\hline 15 & 70.0 & 93.3 & $45.75 \pm 3.53$ & $18.8 \pm 1.42$ & $45.8 \pm 3.53$ & $0.4 \pm 0.03$ & 0 & HT \\
\hline 16 & 63.3 & 86.7 & $45.0 \pm 4.32$ & $17.1 \pm 1.58^{*}$ & $45.0 \pm 4.32$ & $0.4 \pm 0.05$ & 1.67 & ХТД \\
\hline $\begin{array}{c}\text { Контроль } \\
\text { Control }\end{array}$ & 76.7 & 93.3 & $47.54 \pm 2.84$ & $21.0 \pm 10.88$ & $48.4 \pm 2.36$ & $0.5 \pm 0.07$ & 0 & \\
\hline
\end{tabular}


Труды Института биологии внутренних вод им. И.Д. Папанина РАН, вып. 91(94), 2020 г.

Таблица 7. Обобщенные результаты биотестирования воды оз. Неро на различных тест-организмах

Table 7. The summarized results of biotesting of lake water Nero on various test organisms

\begin{tabular}{c|c|c|c|c|c}
\hline Станция & \multicolumn{2}{|c|}{ Ceriodaphia dubia } & Chlorella vulgaris & \multicolumn{2}{|c}{ Lepidum sativum } \\
\cline { 2 - 6 } Station & июнь & август & июнь & июнь & август \\
\hline 1 & - & - & - & + & + \\
2 & - & - & - & - & + \\
3 & - & - & - & - & - \\
4 & - & + & - & + & + \\
5 & + & + & + & + & - \\
6 & + & + & + & + & - \\
$6 \mathrm{a}$ & - & н.д. & + & - & н.д \\
7 & + & + & + & + & - \\
8 & + & - & + & + & - \\
9 & + & + & + & - & - \\
$9 \mathrm{a}$ & + & н.д. & + & + & н.Д \\
10 & + & + & + & - & + \\
$10 \mathrm{a}$ & + & н.д. & + & + & н.д \\
11 & + &.+ & + & + & + \\
12 & - & + & - & - & + \\
$12 \mathrm{a}$ & + & н.д. & + & + & н.Д \\
13 & + & + & + & + & + \\
14 & - & + & - & - & + \\
15 & + & + & + & + & - \\
16 & + & + & + & + & + \\
\hline
\end{tabular}

Примечание. “+”- зарегистрирована токсичность, “-”- токсичность отсутствует.

Note. "+" - registered toxicity, “-" - no toxicity.

Вместе с тем установлено, что содержание нефти и нефтепродуктов на всех исследованных станциях выше ПДК для водных объектов рыбохозяйственного назначения. Обнаруженные концентрации СО3 и ПАУ в воде озера соответствуют фоновым уровням, выявленным в неподверженных антропогенной нагрузке участках Рыбинского водохранилища [Kozlovskaya, German, 1997].

Таким образом, содержание приоритетных загрязняющих веществ в воде оз. Неро, в целом, имеет равномерное пространственное распределение, хотя по ряду показателей на некоторых станциях отмечены отклонения в сторону уменьшения или увеличения. Большинство исследованных загрязняющих веществ присутствуют в воде ниже нормативных уровней, за исключением нефти и нефтепродуктов, меди, для которых выявлено превышение ПДК.

Относительно низкая токсичность природных вод объясняется и характером взаимодействия между фоновыми приоритетными загрязнителями и включением адаптационных механизмов у гидробионтов. Используя только физико-химические методы нельзя с абсолютной уверенностью дать ответ о реальной токсичности элемента в природной среде, поскольку связь токсичности элемента с его концентрацией в среде не всегда является однозначной [Sunda, Lewis, 1978].
Установлены корреляционные зависимости различных тест-функций всех использованных в работе тест-объектов от содержания в воде отдельных полиароматических углеводородов или их суммы (табл. 8). Мышьяк и нефтепродукты оказывали влияние на рост корней кресс-салата, нефтепродукты на гибель цериодафний за 7 сут и число пометов за этот же срок.

Несмотря на содержание меди выше ПДК на некоторых станциях, зависимость токсичности воды от ее концентраций для различных тест-объектов не установлена. Известно, что диапазон перехода от физиологически допустимых концентраций меди к токсическим узок: незначительное повышение активности меди в среде может приводить к морфологическим и метаболическим нарушениям. При этом водоросли более чувствительны к избытку меди, чем высшие растения [Демидчик и др., 2001 (Demidchik et al., 2001)].

Положительные корреляционные зависимости ростовых показателей кресс-салата от содержания в воде ПАУ может свидетельствовать об их ауксиновом действии, выраженном в росте биомассы корней, что неоднакратно подтверждалось и другими исследователями [Тонкопий и др., 1979 (Tonkopij et al., 1979); Яковлева и др., 2008 (Yakovleva et al., 2008)]. 
Таблица 8. Корреляционные связи между гидрохимическими показателями и биологическими параметрами тест-организмов при биотестировании воды

Table 8. Correlation between hydrochemical and biological parameters of test organisms during water biotesting

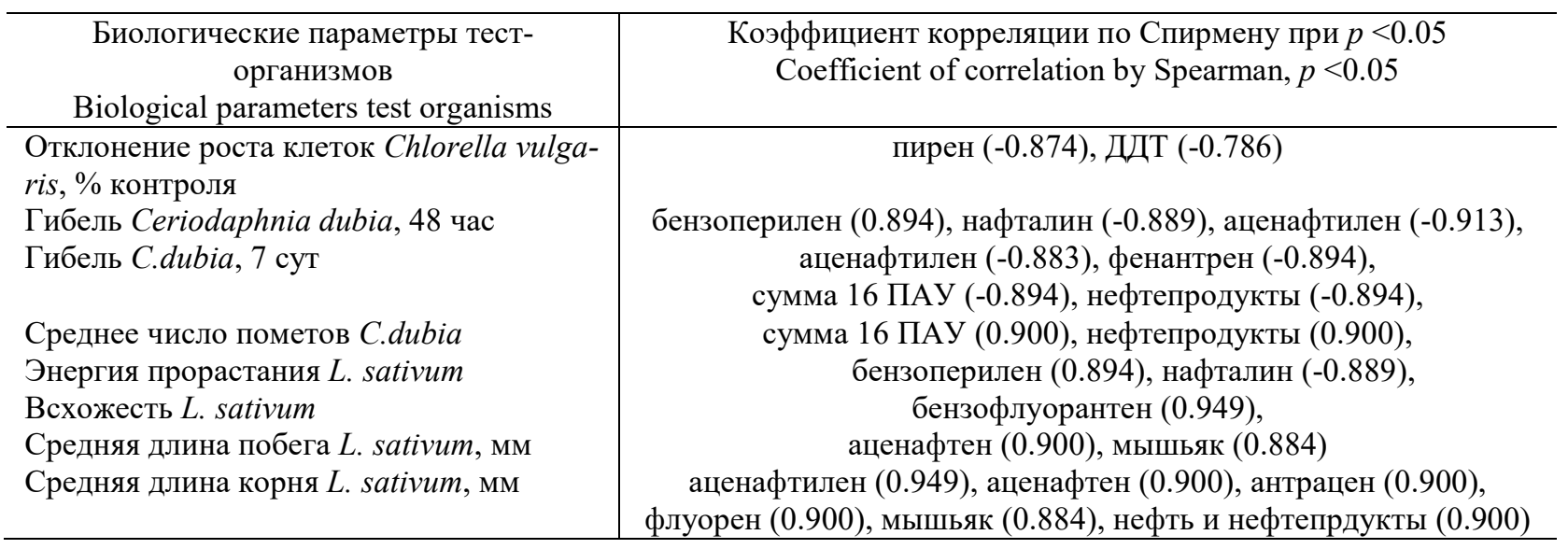

Таким образом, за весь период наблюдений по токсикологическим показателям воды к наиболее благополучным относится только ст. 3, на которой не зарегистрирована токсичность ни по одному тест-организму. Хотя на этой станции зарегистрировано высокое число $(5 \%$, в контроле - 0) число недоразвитых проростков семян кресс-салата (табл. 6). Другими авторами отмечено, что выраженность мутагенной активности воды ст. 3 меняется от 0.5 до 2.28 , составляя в среднем $1.50 \pm 0.10$. Доля проб с зарегистрированным мутагенным эффектом составляет $19 \%$, следовательно, мутагенное загрязнение может быть охарактеризовано как случайное [Ковалева и др., 2013 (Kovaleva et al., 2013)]. Станции 11, 13 и 16 должны быть отнесены к наиболее неблагополучным, так как в пробах воды, отобранных на них, зарегистрирована токсичность по всем тест-организмам в обе даты наблюдения.

\section{ЗАКЛЮЧЕНИЕ}

Впервые проведено исследование токсичности воды высокоэвтрофного оз. Неро. За весь период наблюдений по токсикологическим показателям воды к наиболее благополучным относится только ст. 3 , расположенная севернее о. Рождественский, на которой не зарегистрирована токсичность ни для одного тест-организма. К наиболее неблагополучным - станции 11, 13 и 16, на которых зарегистрирована токсичность для тест-объектов в обе даты наблюдения. На наиболее загрязненных участках озера (ст. 5-8), приуроченных к его северной части, подверженной воздействию бытовых и промышленных стоков г. Ростова, наблюдали хроническое токсическое действие воды в $80 \%$ случаев.

Установлены корреляционные зависимости изменения некоторых тест-функций использованных в работе тест-объектов от содержания в воде отдельных полиароматических углеводородов или их суммы. Мышьяк и нефтепродукты оказывали влияние на рост корней кресс-салата, нефтепродукты на гибель цериодафний за 7 сут и число пометов за этот же срок.

Для объективной оценки качества среды необходимо использовать несколько тестобъектов, относящихся к различным систематическим группам и трофическим уровням.

\section{БЛАГОДАРНОСТИ}

Авторы выражают благодарность В.В. Законнову и А.И. Цветкову за отбор проб воды.

Работа выполнена в рамках государственного задания Министерства науки и высшего образования Российской Федерации “Физиолого-биохимические и иммунологические реакции гидробионтов под действием биотических и абиотических факторов окружающей среды” (№ r/p AAAA-A18118012690123-4), а также в рамках НИР "Комплекс мероприятий по анализу состояния озера Неро и необходимости проведения работ по его комплексной экологической реабилитации”.

\section{СПИСОК ЛИТЕРАТУРЫ}

Александрова В.В. Применение метода биотестирования в анализе токсичности природных и сточных вод (на примере Нижневартовского района Тюменской области). Нижневартовск: Изд-во Нижневарт. гуманит. унта, 2009. 94 c.

Бакаева Е.Н., Никаноров А.М., Игнатова Н.А. Место биотестовых исследований донных отложений в мониторинге водных объектов // Вестник Южного научного центра. 2009. № 2. Т. 5. С. 84-94. 
Брагинский Л. П., Величко И. М., Щербань Э. П. Пресноводный планктон в токсической среде. Киев: Наукова думка, $1987.178 \mathrm{c.}$

Веселов Е.А. Патологические функциональные и морфологические изменения у пресноводных беспозвоночных и рыб под влиянием интоксикации // Норма и патология в водной токсикологии. Байкальск, 1977. С. 111-117.

ГОСТ Р 54496-2011 (ИСО 8692:2004). Вода. Определение токсичности с использованием зеленых пресноводных одноклеточных водорослей. Стандартинформ. 2012. 53 с.

Демидчик В.В., Соколик А.И., Юрин В.М. Поступление меди в растения и распределение в клетках, тканях, органах. // Успехи современной биологии. 2001. Т. 121. № 2. С. 190-197.

Жмур Н.С. Экотоксикологический контроль. Приемы исследования и лабораторная практика. М.: Издательство “Акварос", 2018. 472 с.

Лебедев В.П. Биотестирование загрязнения и токсичности водной среды // Экологическая культура и образование: инновационный опыт Вологодской области. Вологда. 2006. С. 94-98.

Ковалёва М.И., Прохорова И.М., Фомичева А.Н., Ильина К.Г. Исследование токсикогенетического состояния озера Неро, Ярославская область // Вестник АПК Верхневолжья. 2013. № 3 (23). С. 60-65.

Крайнюкова А.Н. Биотестирование в охране вод от загрязнения // Методы биотестирования вод. Черноголовка. 1988. С. 4-14.

Методика определения токсичности питьевых, грунтовых, поверхностных и сточных вод, растворов химических веществ по измерению показателей всхожести, средней длины и среднего сухого веса, проростков семян кресс-салата (Lepidium sativum) // ПНД Ф Т 14.1:2:4.19-2013. М., 2013.

Методика определения токсичности вод, водных вытяжек из почв, осадков сточных вод и отходов по изменению уровня флуоресценции хлорофилла и численности клеток водорослей. ФР.1.39.2007.03223. // М.: “Акварос”. 2007. $48 \mathrm{c.}$

Методика определения токсичности воды и водных вытяжек из почв, осадков сточных вод, отходов по смертности и изменению плодовитости цериодафний. Федеральный реестр (ФР). ФР.1.39.2007.03221. М.: АКВАРОС, 2007. $56 \mathrm{c.}$

Методы оценки токсического влияния фитоценозов планктона на формирование качества поверхностных вод суши. Р52.24.809-2014.

Некрасова И.И. Местные и общие реакции организма на повреждение: Учебное пособие по патологической физиологии. Ставрополь: Ставропольский государственный аграрный университет, 2008. 163 с.

Определитель зоопланктона и зообентоса пресных вод Европейской России. Т.1. Зоопланктон. М.: Товарищество научных изданий КМК, 2010. 495 с.

Состояние экосистемы озера Неро в начале XXI века. М.: Наука, 2008. 406 с.

Тонкопий Н.И., Розанова В.Я., Мазель Ю.Я. Экспериментальное изучение возможности усвоения бенз(а)пирена растениями // Растения и химические канцерогены. Л.: Наука, 1979. С. 97-99.

Фомин Г.С., Фомин А.Г. Почва. Контроль качества и экологической безопасности по международным стандартам: Справочник. М.: Протектор. 2001. 304 с.

Шагина В.В., Афонина Н.С., Ковалева М.И. Изучение динамики мутагенной активности воды высокоэвтрофного озера Неро // Экология и рациональное природопользование, Матер. Всерос. научно-практической конференции. 12-16 сентября 2017 г. Ярославль: ЯрГУ, 2017. С. 170-173.

Яковлева Е.В., Безносиков В.А., Кондратенок Б.М. Биоаккумуляция полициклических ароматических углеводородов в системе почва - растение // Агрохимия. 2008. № 9. С. 66-74.

Kozlovskaya V.I., German A.V. Polychlorinated biphenyls and polyaromatic hydrocarbons in the ecosystem of the rybinskoe reservoir // Water Resources. 1997. T. 24. № 5. C. 520-526.

Mount D.I., Norberg T.J. A seven-day life cycle cladoceran toxicity test // Environmental Toxicology and Chemistry. 1984. Vol. 3. P. 425-434.

Sokal R.R., Rohlf F.J. Biometry: the principles and practice of statistics in biological research. N.Y.: W.H. Freeman and Comp., 1995. 887 p.

Sunda W.G., Lewis J.A.M. Effect of complexation by natural organic ligands on toxicity of copper to a unicellular alga, Monochrysis lutheri // Limnol. Oceanogr. 1978. Vol. 23. P. 870-876.

\section{REFERENCES}

Aleksandrova V.V. Biotesting as a modern method of evaluation of toxicity of natural waters and sewage. Nizhnevartovsk: Nizhnevart. gos. un-ta, 2013. 119 p. (In Russian).

Bakaeva E.N., Nikanorov A.M., Ignatova N.A. The place of biotest studies of bottom sediments in the monitoring of water bodies. Vestnik Yuzhnogo nauchnogo centra RAN. 2009, vol. 5. no. 2, pp. 84-93. (In Russian).

Braginskij L. P., Velichko I. M., Shcherban" Eh. P. Freshwater plankton in a toxic environment. Kiev, Naukova dumka, 1987, 178 p. (In Russian).

Demidchik V.V., Sokolik A.I., Yurin V.M. The intake of copper in plants and distribution in cells, tissues, organs. Uspekhi sovremennoj biologii, 2001. vol. 121. no 2. pp. 190-197. (In Russian).

Fomin G.S., Fomin A.G. The soil. Quality Control and Environmental Safety by International Standards: A Guide. Moscow, Protektor, 2001. 304 p. (In Russian).

Key to zooplankton and zoobenthos of fresh water in European Russia. vol.1. Zooplankton. Moscow. Tovarishchestvo nauchnyh izdanij KMK, 2010. 495 p. (In Russian). 
Kovaleva M.I., Prokhorova I.M., Fomicheva A.N., Ilyina K.G. Study of the toxicogenetic state of lake Nero, Yaroslavl region. Vestnik APK Verhnevolzh'ya, 2013, vol. 3 (23). pp. 60-65. (In Russian).

Kozlovskaya V.I., German A.V. Polychlorinated biphenyls and polyaromatic hydrocarbons in the ecosystem of the Rybinsk reservoir. Water resources. 1997. vol. 24. no 5. pp. 520-526.

Krainyukova A.N. Biotesting to protect water from pollution. Metody biotestirovaniya vod [Aqua ratio biotesting]. Chernogolovka. 1988. pp. 4-14. (In Russian).

Lebedev V.P. Biotesting of pollution and toxicity of water environment. Ekologicheskaya kultura i obrazovanie: innovacionnyj opyt Vologodskoj oblasti [Educationem environmental et culturae: regionem innovative usus Vologda]. Vologda, 2006. pp. 94-98. (In Russian).

Methods for assessing the toxic effects of plankton phytocenoses on the formation of land surface water quality. R 52.24.809-2014. (In Russian).

Mount D.I., Norberg T.J. A seven-day life-cycle cladoceran toxicity test // Environ. Toxicol. Chem., 1984, vol. 3, pp. 425434.

Nekrasova I.I. Local and general body reactions to damage: A training manual on pathological physiology. Stavropol'skij gosudarstvennyj agrarnyj universitet. Stavropol', 2008. 163 p. (In Russian).

Shagina V.V., Afonina N.S., Kovaleva M.I. Study of the dynamics of the mutagenic activity of water in the highly eutrophic lake Nero. Vseros. nauchno-prakticheskoj konferencii. Ekologiya i racional'noe prirodopol'zovanie [AllRussian scientific and practical conference Ecology and rational nature management]. Yaroslavl': YarGU 2017, pp. 170-173. (In Russian).

Sokal R.R., Rohlf F.J. Biometry: the principles and practice of statistics in biological research. N.Y.: W.H. Freeman and Comp., 1995. $887 \mathrm{p}$.

State Standart R 54496-2011 (ISO 8692:2004). Water. Determination of toxicity using green freshwater unicellular algae. Standartinform, 2012. 53 p. (In Russian).

The methodology for determining the toxicity of water and water extracts from soils, sewage sludge, waste by mortality, changes in the fecundity of ceriodaphnia. Federal'nyj reestr (FR). FR 1.39.2007.03221. Moscow: "Akvaros", 2007. 56 p. (In Russian).

The methodology for determining the toxicity of drinking, ground, surface and wastewater, chemical solutions for measuring germination rates, average length and average dry weight, seedlings of watercress (Lepidium sativum). 2013. PND F T 14.1:2:4.19-2013. Moscow, 2013. (In Russian).

The methodology for determining the toxicity of water, water extracts from soils, sewage sludge and waste by changing the level of chlorophyll fluorescence and the number of algae cells. FR. 1.39.2007.03223. N.S. Zhmur, T.L. Orlova. Moscow “Akvaros”, 2007. 48 p. (In Russian).

The state of the ecosystem of lake Nero at the beginning of the XXI century. Moscow: Nauka, 2008, 406 p. (In Russian).

Tonkopij N.I., Rozanova V.Ya., Mazel' Yu.Ya. Experimental study of the possibility of assimilation of benz(a)pyrene by plants. Rasteniya i himicheskie kancerogeny. Leningrad: Nauka, 1979, pp. 97-99. (In Russian).

Veselov E.A. Pathological functional and morphological changes in freshwater invertebrates and fish under the influence of intoxication. Norma i patologiya v vodnoj toksikologii. Bajkalsk, 1977, pp. 111-117. (In Russian).

Yakovleva E.V., Beznosikov V.A., Kondratenok B.M. Bioaccumulation of polycyclic aromatic hydrocarbons in the soil plant system. Agrohimiya. 2008, vol. 9, pp. 66-74. (In Russian).

Zhmur N.S. Ecotoxicological control. Research methods and laboratory practice. Moscow: "Akvaros”, 2018,472 p. (In Russian)

\title{
TOXICOLOGICAL STUDIES OF A SHALLOW WATER OF HIGH EVTROPHIC LAKE NERO (YAROSLAV REGION). MESSAGE 1. WATER
}

\author{
I. I. Tomilina, R. A. Lozhkina, I. V. Chalova, N. S. Shevchenko \\ Papanin Institute for Biology of Inland Waters Russian Academy of Sciences, \\ Borok, Nekouzskii raion, Yaroslavl oblast,152742 Russia, e-mail: i_tomilina@mail.ru
}

For the first time, a study of the water toxicity of the highly eutrophic lake Nero was conducted using bioassay methods. For the entire period of observations on toxicological indicators of water, only station 3 , located north of Rozhdestvensky Island, where toxicity was not registered for any test organism belongs to the most successful ones. The most unfavorable stations are stations 11, 13 and 16, which registered toxicity for all test organisms on both dates of observation. In the polluted areas of the lake (art. 5-8), confined to its Northern part, exposed to domestic and industrial wastewaters of Rostov City, chronic toxic effects of water were observed in $80 \%$ of cases. The correlation dependences of changes in some test functions of the test objects used on the content of individual polyaromatic hydrocarbons in water or their sum have been established. Arsenic and petroleum products had an impact on the growth of watercress roots, petroleum products influenced the death of Ceriodaphnia for 7 days and the number of brood during the same period. For an objective assessment of the quality of the environment, it is necessary to use several test objects belonging to different systematic groups and trophic levels.

Keywords: water, toxicity, bioassay, Lake Nero 